Jpn. J. Spec. Educ., 44 (6), 523-541, 2007.

\title{
Review
}

\section{Legislation and Policy of a Developing Inclusive Education Service and Social Inclusion of People With Special Needs in Hungary as a European Union Member State}

\author{
Gabor TOTH
}

\begin{abstract}
Inclusive education and full social inclusion of people with special needs into mainstream education and transition to employment are topics that have drawn attention in the special education literature. The main purpose of the present paper is to give an overview of the current situation and problems within the EU; especially in Hungary, as it has special characteristics. Another aim of the present paper is to provide information for special education professionals who are searching for an open solution towards effective inclusion of people with special needs in Japan. Following an overview of special education and inclusive education generally, the paper focuses on problems and their solution within the EU and Hungary.
\end{abstract}

Key Words: people with special needs, special education, social inclusion, EU and Hungary

\begin{abstract}
"The needs of Education for All $\cdots$ include both the necessary volume of knowledge and skills $\cdots$ and the fundamental contents of education $\cdots$, that are necessary to the people in order to survive, develop all their capabilities, exist and work respecting human dignity, participate multilaterally in the development and improvement of the quality of their lives, make balanced decisions and continue their studies"
\end{abstract}

(UNESCO, 1990)

\section{Introduction}

The author of the present article is a Hungarian special education teacher and researcher, and thus an authentic writer on the present theme.

The Republic of Hungary is a small country in Central Europe with a population of 10,090,330 (HCSO, 2005), bordered by seven other countries. Its geographical features and more than a thousand-year European history have resulted in strong connections with the neighbouring states. This strong relationship among countries

Yokohama City University Graduate School of Medicine 
and cultures had its effect on the development of both the Hungarian and other European education systems (Ration Educationis, Maria Theresa, 1777).

The Hungarian special education system has special characteristics in Europe. The first special education institute for students with hearing disabilities opened its doors in 1802. During the next hundred years, Hungarian special education schools and institutes were under the influence of the German and Austrian "Heilpädagogik" with strong working collaborations. The connections and traditions of "Heilpädagogik" did not stop even after the strong medical and educational influence of the Russian "defectology" began in 1945.

In 1902, Hungary organised the world's first psychological laboratory for research on developmental disabilities, under the leadership of Prof. Pál Ranschburg. "Heilpädagogik" and "defectology" still influence the Hungarian special education system, which makes it historically unique in the world.

Hungary has been a member state of the European Union (EU) since May 2004. In the EU, education is the responsibility of Member States, and EU institutions play only a minor role. On the other hand, the EU has worked on various harmonisation projects since the 1980's, including the Helios Programme, which is related to social inclusion and work issues.

The Helios Programme was the result of the new inclusion-oriented education policy of the Council of the European Union (European Council, 1990). This new policy states that within the Member States, full inclusion should be the future form of education and, later on, of employment as well.

The Treaty of Maastricht (European Council, 1992) provides for an extensive contribution of the European Community to education and vocational training. According to Article 149 of the Treaty of Amsterdam (European Council, 1997), the EU "shall contribute to the development of quality education by encouraging cooperation between Member States," promoting the mobility of citizens, designing joint study programmes, establishing networks and exchanging information. This Treaty also contains a commitment to promote life-long learning for all citizens of the EU. Thus, the EU funds educational, vocational, and citizenship-building programmes that encourage EU citizens to take advantage of opportunities to live, study, and work in other countries (Whittle, 1998).

In summary, the potential provided by the Treaty of Amsterdam is substantial for the advancement of disability rights, because it points out the right of people with special needs (SN), to act like all other citizens of the EU and to take advantage of the quality citizenship and barrier-free educational/vocational opportunities in the Community (Whittle \& Cooper, 1999). Nowadays, the new educational policy of the EU has already resulted in the development between 2000 and 2006 of thirdgeneration education-related programmes like Socrates (education) and Leonardo (vocational training and lifelong learning).

Each Member State has a coordinating contact called the National Agency, which acts as the main national contact point for help and advice on all related programmes. As part of their role, the National Agencies conduct regular events and 
offer help throughout an application process. At the Community level, these programmes are managed by the European Commission and, at the national level, by the National Agencies (Halász, 2004).

The main problem in developing the best possible inclusive education projects within the EU is differences in the definition of "children with special needs" across the Member States. There are great differences in the reported percentage of children with special needs across European countries (see Fig. 1) (EADSNE, 2003b). The reason for this is not biological or social, but rather is related simply to the definition of "children with special needs".

Table 1 shows that, in practice, the special education system has three main forms within the EU. One system (mainstream) includes nearly all children in the same school system; with only a few experiencing segregated education. The term

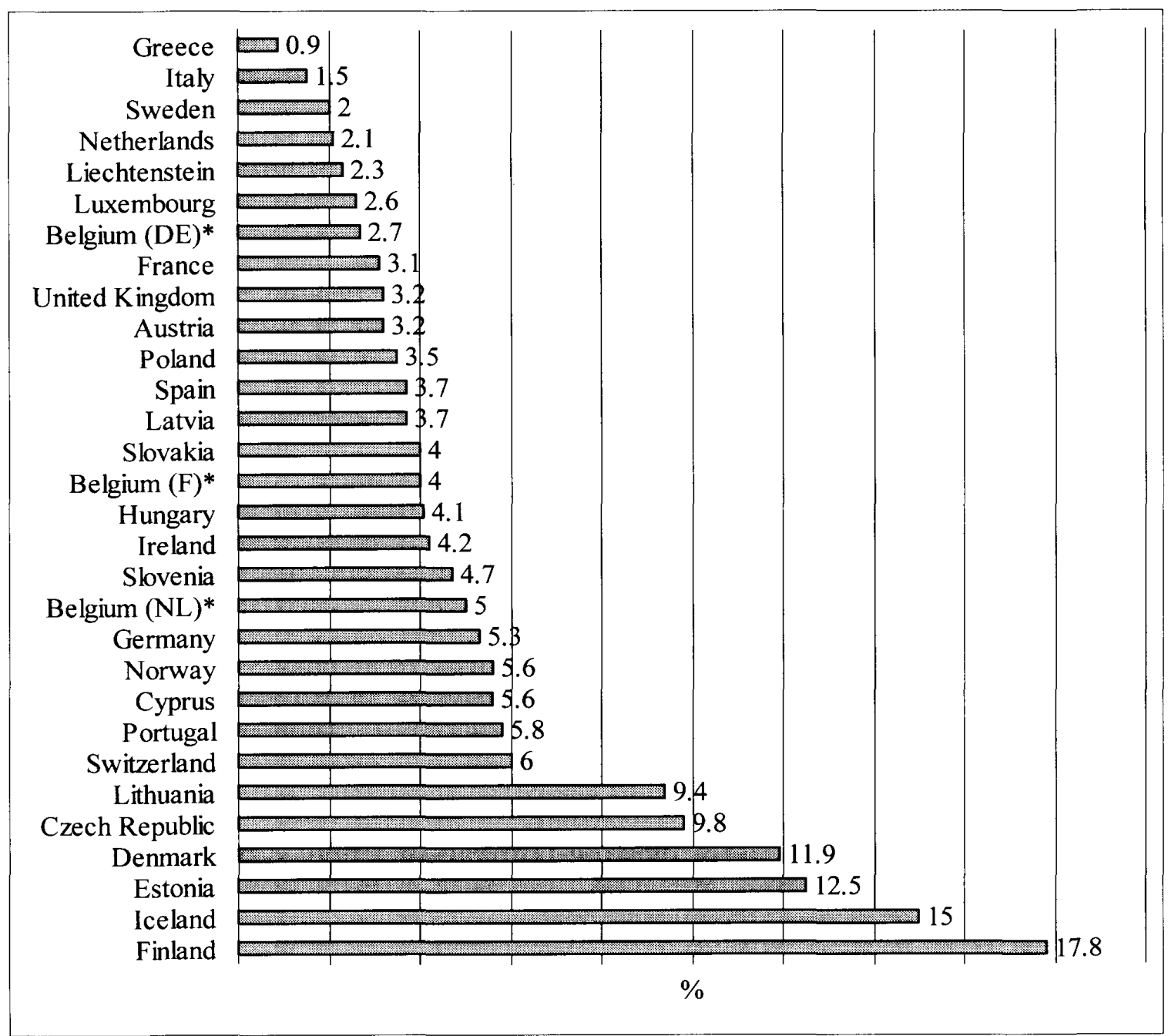

Fig. 1 Ghildren With Special Needs Within the School-Age Population in 28 Countries of Europe

Notes. * Belgium has 3 community regions: $\mathrm{DE}=$ German; $\mathrm{F}=$ French; $\mathrm{NL}=$ Flemish, where the official data differ (EADSNE, 2003b). 
TABLE 1 Types of Inclusive Education Systems in 20 European Countries (EADSNE, 2003a)

\begin{tabular}{clc}
\hline \multicolumn{1}{c}{ Type } & \multicolumn{1}{c}{ Characteristics } & Number of Countries \\
\hline \multirow{2}{*}{ One-track systems } & all children in the same school system, & 8 \\
Multi-track systems & with strong professional advocacy & 12 \\
Two-track systems & two clearly separated school systems & 2 \\
\hline
\end{tabular}

"segregated" here refers to special schools and full-time/almost full time special classes. The second is a mixed system, including many possible variations in the extent of integrated and segregated education. In the third type, regular and special education are separated (EADSNE, 2003a). Data reporting the extent of segregated education in Europe are shown in Fig. 2.

One of the main characteristics of the Hungarian special education system is that Hungary belongs to the group of countries that strongly segregate students with special needs for education. At present, inclusive education, which is mainly characteristic of the first cycle of general school education, is continuously developing, and is initiated in most cases by parents.

The main problem with inclusive education is that the educational requirements for students with disabilities are identical to those for students without disabilities. This fails to take into consideration the special curricular requirements of students with special needs. Inclusive education requires that, in the future, the public school systems develop appropriate Individualized Education Programs (IEP) for each child with special needs.

In 1993, the Hungarian Public Education Act and the Equal Opportunities Act established a legal framework for inclusive education. However, implementation and enforcement of these laws requires decades of development and investment.

The present review cannot mention all the problems related to the concept of inclusive education and social inclusion, which is strongly related to inclusive education. However, the main difficulty lies in the definition of these two concepts. One definition of inclusive education includes the idea that "Inclusion implies radical reform ‥ [of] curriculum, assessment, pedagogy, and grouping of pupils" (Mittler, 2000, p. 10).

Introduction of inclusion in the existing Hungarian school system involves a very complex educational and socio-political change. To fall within the EU's requirements for inclusion would mean changing mainstream schools to make them more responsive to the needs of all children. Of course, introducing inclusive education is not the same as reforming the existing segregated special education system. In the future policy of the EU, there is a place for only one school system for all pupils (EUMAP, 2005).

On the other hand, the definition of social inclusion can be seen more as a strategy of the government, a policy of closing the distance between people with and 
without disabilities. From this viewpoint, the problem with the Hungarian system is multifactorial. These factors include the previously mentioned problems of the general curriculum and assessment, as well as elements of inclusive practice, preparation of professionals for inclusive education, parent involvement, and a future agenda for inclusive schools. In practice, this means providing positive action in all sectors of society in planning and decision-making (National Disability Programme, 1999). In other words, the linked problems of social inclusion in Hungary are related to the economic, social, and environmental well-being of people with disabilities, namely unemployment, poor living skills, low income, poor housing, bad health, and family breakdown (EUMAP, 2005).

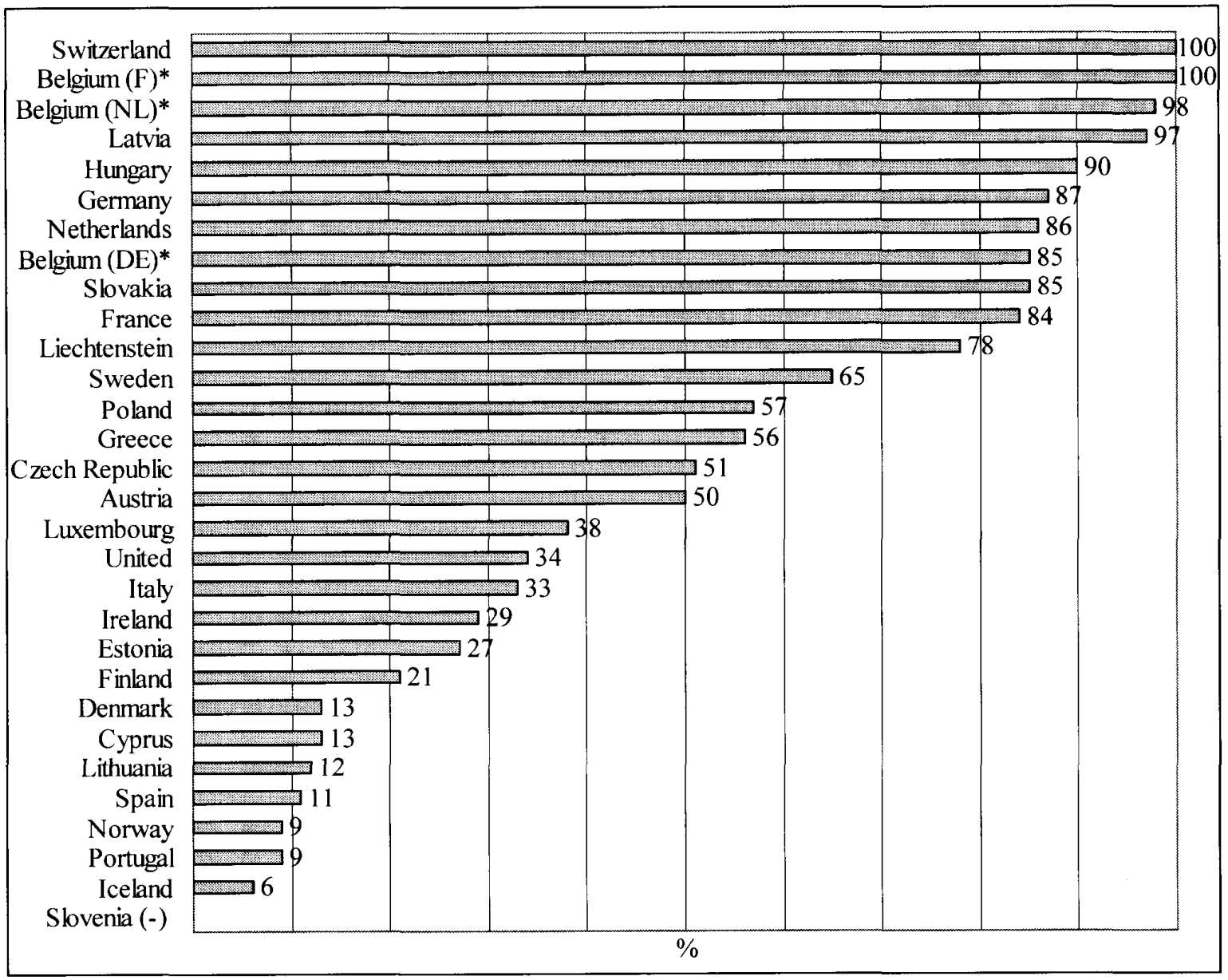

Fig. 2 Percentage of School-Age Pupils in Segregated Education in 28 European Countries

Notes. 1) Belgium has 3 community regions: $\mathrm{DE}=$ German; $\mathrm{F}=$ French; $\mathrm{NL}=$ Flemish, where the official data differ (EADSNE, 2003b).

2) "Segregated" refers to special schools and full-time/almost full-time special classes. 


\section{Overview of Special Education and Policies on Social Inclusion of People With Special Needs in the EU and Hungary}

Special education issues, and the urgent need for policy and legislation related to inclusive education of people with special needs, pressed the European Council to order a report on the following issues and key actions at the EU level (European Council, 2001):

- facilitation of inclusion into mainstream education,

- development of the role played by specialised institutions in promoting the development of inclusive education,

- development of active cooperation between the education services and other related services,

- encouragement of the formulation of comprehensive and coherent policies with regard to education, and

- overcoming of difficulties that mainstream educational programmes may present for children and young people with special needs.

The main purpose of the European Commission in declaring 2003 to be the European Year of People with Disabilities was to drive forward the political agenda of full inclusion of people with special needs and to develop a barrier-free Europe for them. These acts were very important for the development of new Hungarian policy and legislation issues, just prior to Hungary being granted full membership in the EU in May 2004. This new policy and legislation included the following competencies and key actions at the national level:

- to take new concrete action to have better access to teaching and training in a lifelong learning perspective for people with special needs (European Council, 2003a),

- to tap the information society's potential for people with special needs, and to tackle the removal of technical, legal, and other barriers to their effective participation in a knowledge-based society (European Council, 2003b),

- to take new concrete action to improve access for people with special needs to the cultural infrastructure, cultural activities, and the media (European Council, 2003c).

\section{Segregation and Inclusion in Education and Employment in Hungary}

The main legislation governing public education, including special education, in Hungary is the Public Education Act (Act LXI of 2003 on the Amendment of Act LXXIX of 1993 on Public Education, 2003). In the context of this Act, with respect to education for children with special needs, education is to be given to children at special schools according to the category and degree of their disabilities.

Hungary also has a comprehensive disability policy (Disabled Persons Act, 2004) and a related National Programme on Disability Affairs, which incorporates international standards related to the social inclusion of people with special needs. However, access to inclusive education and supported employment for people with special 
needs is still limited (EUMAP, 2005).

At the present time, at the basic education level, the main educational system is still highly segregated. Children with various special needs are educated in special schools; only a few attend mainstream education. For example, in 2001-2003, only 5, 598 primary school children with intellectual disabilities were studying in mainstream schools, whereas 32,231 were registered in special schools.

The Hungarian special education system segregates children according to the type and level of their disabilities (Köpatakiné Mészáros \& Singer, 2005). On the other hand, Hungarian special schools have a strong tradition, and provide good quality education (Gordosné, 2004).

The Hungarian special education system reached its "bicentenary age" in 2002. The country report related to the education and employment of people with intellectual disabilities of the Open Society Institute-EUMAP shows that, regardless of the quality of special education, segregated special schools do not prepare students for social inclusion or employment on the open labour market (EUMAP, 2005). One of the reasons for this is the gap between education and employment, because special education curricula do not include necessary knowledge or provide the skills needed to compete on the open labour market. Furthermore, most of the training programmes and special vocational schools available for adults with special needs do not offer marketable skills, and only a few companies offer long-term employment with fair salaries within the labour market.

The Hungarian government promotes the employment of people with special needs through a quota system: $5 \%$ of staff at companies employing more than 20 people must be employees with altered working capacity (Employment and Social Care of People with Altered Working Capacity, 2004). There are also State subsidies and tax incentives.

However, progress in this area is not yet acceptable. The quota system has not been effective, because the penalty for not hiring a full quota is too low, and the tax incentives available for hiring people with altered working capacity are not very attractive. The country report of the Open Society Institute-EUMAP shows that approximately $90 \%$ of people with intellectual disabilities in Hungary do not have employment on the open labour market, and the few who do work mainly in sheltered workplaces.

In the near future, an employment-based curriculum should be introduced. Furthermore, the Hungarian government should develop partially state-funded supported employment services so as to prepare people with special needs for work in the open labour market by offering day by day support and coaching (EUMAP, 2005).

In Hungary, the main reference for the differential diagnosis of disabilities is the World Health Organisation's ICD-10 (World Health Organization, 1992). Diagnosis and assessment for educational purposes are the duty of the Professional Committees for Assessing Learning Abilities (31 committees). These Committees are multidisciplinary and generally composed of highly skilled professionals, such as psychologists, 
special educators, and medical professionals, but the Committees are extremely overburdened by heavy workloads which include initial assessment, re-assessment, consulting and counselling, and early intervention services.

The established system in which specialised institutions are chosen by the children's parents is maintained by the Law of Public Education. Educational teaching institutions are chosen by parents based on the professional advice of the professional and rehabilitational committee investigating their child's learning abilities, or that of the national professional and rehabilitational committee, according to the Law. The Law says that students needing special education may attend an educational teaching institution that possesses the personnel and material conditions that will ensure the students' special education and teaching needs. Based on the Committee's findings and opinion, they officially recommend a school type to the family. After that, it is the parents' choice to accept it or appeal.

According to the Public Education Act, the State has an obligation either to educate or, in the case of children with severe and/or multiple disabilities, to train, all children regardless of their disabilities. That is, the obligation to train applies only to children with severe and/or multiple disabilities. The special school system, which is based on the Public Education Act, is called a two-tier system, in which children classified as "educable" receive 20 hours of lessons per week in a special school or in some cases mainstream school, and those classified as "trainable" receive five hours of training or stimulation per week at home or in groups at special training institutions.

As a result of this system, a large number of children with severe disabilities, at present up to 2,500 (EUMAP, 2005), are legally excluded from any form of education other than the specified training. The Public Education Act provides for travelling special educators, yet it does not identify a source of funding for them.

The Government should re-establish its special education policy, discard the two-tier classification system, and give equal educational opportunities to all. Furthermore, the Government should guarantee appropriate methodological, technical, financial, and human resources to make home schooling a standard option and to ensure that all children receive adequate support tailored to their individual needs.

Diagnosis and assessment for employment purposes, and for access to social benefits for adults, is the duty of the National Medical Expert Institute (OOSZI). In Hungary, many of the people with special needs, especially those with intellectual disabilities, when they reach age 18, are placed under guardianship by the courts. There are two forms of guardianship in Hungary, partial and plenary. People under partial guardianship have the right to work, but the civil capacity of people under plenary guardianship has been cancelled completely.

The assessment results of the OOSZI are expressed as a percentage of altered working capacity. Labour offices and local health services jointly conduct assessments of employment capacity. The assessments are conducted entirely by medical doctors who focus on health and medical conditions. Therefore, the assessment system needs to be comprehensively reformed. The Government should take steps to restructure 
the sheltered employment system in order to establish capacity-developing special schools (lifelong education) and training, so as to ensure that people with special needs receive certificates that are recognised by employers on the open market, and in order to improve employment services for people with special needs.

\section{Brief Statistical Overview}

Most of the data available on people with special needs are collected by schools and residential institutions. For decades, statistical investigation of people with disabilities was not possible within the framework of the national census. In the 1990 census survey, a sample of one-fifth of the population had the opportunity to answer questions about having special needs, whereas in 2001, this was extended to the entire population (see Fig. 3).

At the present time, the main source of information on people with special needs is the 2001 National Population Census (HCSO, 2001). The 2001 Census questionnaire contained questions related to "deficiency" (the questionnaire used this term instead of "disability" or "special needs"), whereby people could indicate if they had a "deficiency" in any of the categories listed (HCSO, 2001). The results of the Census 2001 are the first data of this kind that have been obtained in Hungary. They provide information on the detailed characteristics of people with special needs.

However, collecting data on people's "deficiencies" is an enormous challenge, because it is done by self-report. "Answering the following questions is not compulsory!" states the questionnaire (HCSO, 2001).

Table 2 shows data from the 2001 Census on the number of people with special needs in 1990 and 2001. In my opinion, self-reporting may not be the most appropriate means of data collection about deficiencies, due to the social stigma that is still associated with disabilities and special needs. A very high percentage of people with intellectual disabilities are in institutional care in Hungary. Only a few day-care centres provide an alternative to residential care (EUMAP, 2005).

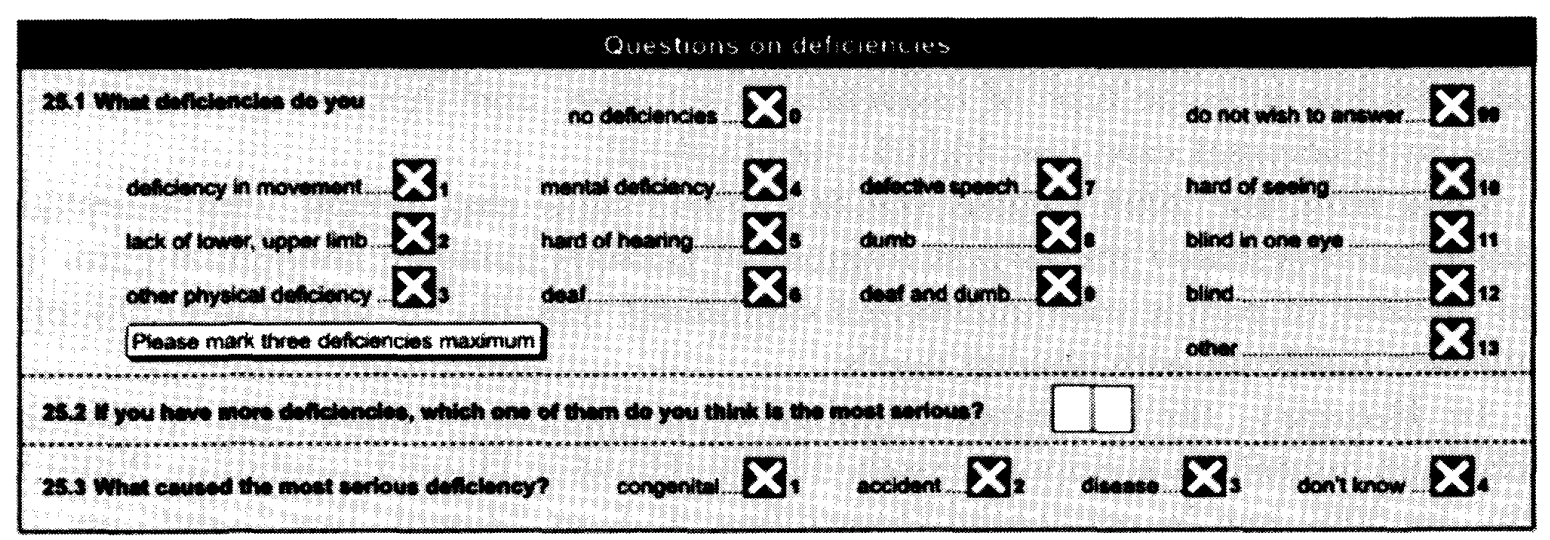

FiG. 3 A Portion of the 2001 Population Census Questionnaire: Questions About "Deficiencies" (HCSO, 2001) 


\section{G. Toth}

TABLE 2 Age Profiles of People With Special Needs in Hungary, 1990 and 2001 (HCSO, 2001)

\begin{tabular}{ccc}
\hline \multirow{2}{*}{ Age Group } & \multicolumn{2}{c}{ Number of People with Disabilities } \\
\cline { 2 - 3 } & 1990 & 2001 \\
\hline $0-14$ & 33,485 & 28,803 \\
$15-59$ & 195,910 & 289,529 \\
$60+$ & 138,875 & 258,674 \\
Total & 368,270 & 577,006 \\
\hline
\end{tabular}

TABLE 3 Number of People With Special Needs Living in Residential Institutions (HCSO, 2001)

\begin{tabular}{lc}
\hline \multicolumn{1}{c}{ Type of Institution } & Number of Residents \\
\hline Specialised institutions for protection of children & 3,405 \\
Dormitories, student hostels & 5,512 \\
Social institutions for long-term lodging & 32,035 \\
Social institution offering temporary lodging & 1,377 \\
Other (e.g., monasteries, group homes) & 3,375 \\
Total & 45,704 \\
\hline
\end{tabular}

According to the inclusion-related amendments of the EU, there is an urgent need for people with severe and/or multiple disabilities to be given equal access to education and guidance in the transition to employment in a non-residential setting.

Types of residential institutions for people with special needs in Hungary include specialised institutions for the protection of children (orphanages), child welfare homes with elementary services, dormitories and student hostels (special boarding schools), social care homes for long-term and temporary lodging, rehabilitation centres, and group homes (e.g., centres for elderly people, homes for people with mental health problems).

From the data of the 2001 Census, the HCSO reports that $8 \%$ of people with disabilities live in some type of residential institution, and that the total number of people in residential care was 45,704 (see Table 3).

Data from the 2001 Census (HCSO, 2001) show that people with intellectual disabilities represented the largest number of persons living in residential care. The total number of people with intellectual disabilities was 21,718 , which is $47.5 \%$ of all institution residents with special needs.

In Hungary, the estimated number of people with severe and/or multiple intellectual disabilities is approximately 11,000 (Hand in Hand Foundation, 2003). Of these, $40-50 \%$ live in residential institutions, and, at present, this is the only real option for them. The reason for this lies in the low number of special education professionals and staff qualified to work with this group in rural areas. 
These data show that Hungary faces a big challenge in establishing an EU norm in deinstitutionalisation and the promotion of social inclusion with appropriate child and family welfare services.

\section{Challenges, Commitments, and Future Recommendations for an Inclusive Education Within EU Standards}

\section{Special Schools as Centres for Educational Counselling}

According to current trends in the EU, the profile and function of special schools for people with special needs should change so that they become local centres for educational counselling and special education. The origin of this trend is the strong political lobby of professional societies, parents' associations, and self-help groups of people with disabilities. Since the late 1960's, they have fought for a well established community-based support system at the local district level, in which local special schools utilise the specialties of their professional teachers, their facilities, and equipment in the community, functioning as centres for counselling on special education.

This new trend appears not only in the EU programme, but also in the New Course of Study in Japan and in Korean special education reform as well (Fujita, 2000; Kim, 2006; NISE, 2000). This movement will provide positive help for the process of decentralisation and deinstitutionalisation of the special education system.

In the case of the Hungarian public school system, it is important to keep a balance between developments in inclusive education and the present segregated school structure, which is working well. The process of transition to an inclusive education system has to be well controlled, continuous and qualitative. There will be a need for special schools in the future as well (Croll \& Moses, 2000; Hornby, 1999), but they need to develop new policies for an appropriate coexistence with the policy of inclusion, in order to enable parents to choose a special school placement for their child if that is their well-regarded opinion (Evans \& Lunt, 2002).

According to the Hungarian Public Education Act, parents always have the final decision related to their children's schooling. On the other hand, there has been no legal base or law forcing mainstream schools to accept children with special needs. That is why, in accordance with the inclusion-oriented education policy of the EU (European Council, 1990) and the Treaty of Maastricht (1992), the Hungarian government has passed a new policy strategy for combating social exclusion by developing an inclusive educational framework and social inclusion strategy for accessibility and equal opportunities (Decree No. 2321/2003, XII.13).

The well established segregated special schools and the new inclusion-oriented mainstream education in Hungary have a number of meeting points. When developing programs, institutions educating children with special learning needs must consider the published guidelines on special education starting from kindergarten. The changing profile and function of the special schools as educational counselling centres include: training programmes for developing a supportive attitude for parents and day-care teachers; programmes facilitating early diagnosis and early develop- 
ment; improvements in the human and material resources of schools accommodating inclusive educational programmes; provision of support services, such as the development of a network of travelling special educational needs teachers; information exchange and the promotion of cooperation in the smaller regions of the country; and organising integrated camps.

In Hungary, reform of the formerly segregated special institutions into source centres and education-supplying institutes has accelerated in the past two years. In this way, the formation of a system of professional support institutes and support of the practice of joint education may be realised. Active participation of schools now providing segregated education gives an opportunity for in-service teacher training, which will help to develop the quality and content of the communication with parents and fulfil the tasks and special duties of professionals.

\section{Individual Inclusion Plans}

One of the first steps in the process of inclusion is the development of an individualised inclusion plan (IIP) for each person with special needs (Mittler, 2000). The IIP is not the same as the individual education plan (IEP) or the individual developmental/therapy plan (IDP).

IEP/IDPs are concerned with helping people to reach specific educational and developmental objectives (Putnam, 1998). The idea and design of the IIP goes beyond the traditional assessment of the specific needs and difficulties of a person with special needs. The basic question of the IIP is what kind of environmental changes would be needed to enable the individual needs of the person to be met in a local mainstream school (Mittler, 2005). The second level in the development of an IIP is to find an answer for this basic question. Thus, assessment of the needs of the individual should be followed by a decision on the removal of difficulties and a detailed time table for doing so. The answer for how to do it and what to do is the development of the IEP/IDP, which thus becomes a continuously maturing process according to the progress of the individual (Dew-Hughes \& Blandford, 1999). Therefore, an IEP/IDP should be set up for each person with special needs, and educational/therapeutic activities should be provided as an action-plan reacting to the goals of IIP.

\section{Cooperation With Educational, Social, Welfare and Medical Institutions}

In recent years, mainly as a result of the accession to the EU, Hungary has taken a number of important steps to improve the situation of people with special needs, and the legislative basis for social and educational inclusion has been strengthened. The National Programme on Disability Affairs establishes the basic structure, mission, and goals of disability policy, although the programme has not been updated since its adoption in 1999 (National Disability Programme, 1999).

To further secure the results of social and educational inclusion, a study by the Open Society Institute-EUMAP (EUMAP, 2005) points out the importance of cooperation with relevant organisations such as medical, welfare, and labour institu- 
tions. I would like to stress that one of the most important steps towards full social inclusion is to establish a multidisciplinary-system in which all members of official agencies are moved to cooperate with one another under the leadership of the government. Previously these institutions had good cooperation with each other, but mainly on a personal level. Now, with the EU regulations, they must act together formally, as regional and international governmental bodies.

The approach to questions dealing with disability considers inclusion as the key solution for establishing a community in which people with disabilities take part in active society. Today, the question is no longer if children with special needs should study together with other students or in separate specialised institutions. The question is been modified to how can we arrange is so that children with special needs can study together with other students. The answer is multidimensional and needs interdisciplinary effort from the institutions involved.

\section{Promotion of an Early Intervention Network and Educational Counselling for Young Children With Special Needs and Their Parents}

Early childhood intervention (ECI) is a term that describes a wide range of multi-disciplinary services offered to children with special needs between birth and school-entry age. Early childhood intervention programs incorporate a broad range of professional services that address the full spectrum of issues associated with developmental disabilities, in order to ensure that the development of each child is maximized. Presently, there is an urgent need for more early childhood intervention centres, where a multidisciplinary team manages a counselling and advice department, supporting infants and young children with special needs and their parents.

The mission of a well coordinated early childhood intervention network is:

- to identify the needs of early development and educational counselling in the community (EADSNE, 2003b),

- to provide educational counselling and advice,

- to provide active treatment and habilitation for infants and young children with special needs,

- to integrate knowledge and skills from previous experiences and foster an open-information centre, and

- to provide opportunities for professionals to participate as team members under supervision and to organise professional training.

Early childhood intervention services and the resources necessary for them (e.g., capital, equipment, personnel) are provided by many different sources, including government and non-governmental and non-profit organizations partly funded by the State. In addition, significant financial and professional help is provided by the European Agency for Development in Special Needs Education (EADSNE). This independent, self-governing organization was established by member countries to act as their platform for collaboration in the field of special needs education. It is maintained by the Ministries of Education within member countries.

Early childhood intervention is an important topic of EADSNE's work. EAD 


\section{G. Toth}

SNE provides sufficient resources for early childhood intervention projects in the EU, with the goal of developing effective early childhood intervention services based on a state-of-the-art, research-based developmental-systems model for guiding children from birth to 5 years of age. Based on the diagnosis established by physicians, neurologists, audiologists, and other professionals, and supporting the children with special needs with needed tools and instruments such as amplification devices, eyeglasses, canes, and crutches, the development of the children's skills and abilities starts as early as possible. The extent course of this program depends on the type and extent of each child's disability. The purpose of early intervention is to focus on problems in the children's and parents' environment and provide counselling in relation to the children's specific disabilities so that the children develop maximally.

There are three main professional resources for early childhood intervention services: hospital-based services, home-based services, and centre-based services. Early intervention programs offer a range of services: diagnostic and assessment services, medical assistance, developmental therapy, physical therapy, psychological services, education-related services, support and information services for families, case management, awareness-raising, and advocacy. The first two Early Childhood Intervention Centres opened in 1992. In Hungary, there has been an annual national conference on early childhood intervention since 1994.

\section{Conclusions}

Hungary, one of the countries that became a member of the EU in 2004, continues to demonstrate economic growth. Hungary gets nearly one-third of the foreign direct investment that has flowed into Central Europe since 1989. However, credit rating institution data show that, as of June 2006, the sovereign foreign currency debt of Hungary is level $\mathrm{BBB}+$, so that Hungary (and Poland) cannot enjoy an A grade score in the EU (EIU, 2006). Inflation and unemployment have been on the rise in the past few years, and they are expected to rise further. Economic reform measures such as health care reform, tax reform, and local government financing have not yet been well addressed by the present government.

Hungary's economic difficulties will continue to block access to inclusive education and transition to employment for people with special needs. Hence, Hungary has to continue to reach toward the goals of the amendments of the Salamanca Declaration (UNESCO, 1994) and the Treaty of Amsterdam (European Council, 1997) with the continuous support of the future-oriented third-generation EU Programmes and UNESCO management practices (UNESCO, 2001) related to inclusion.

Since its accession to the EU, Hungary has been eligible for EU Structural Funds. These will be used in many areas to support new projects for people with special needs, such as inclusion into mainstream schools, school infrastructure development, and lifelong learning. A decentralised education system should allow teachers, schools, and education committees to contribute and/or develop new curriculum designs and programmes, in accordance with the National Core Curricu- 
lum (NAT) and the Curriculum Guidelines for School Education of Children with Disabilities (Gurriculum Guidelines for Children with Disabilities, 1997; Toth, 1997a).

Hungarian public opinion is nearly undivided about the beliefs that it is important to grant equal opportunities to students with special needs, and that the government should provide the necessary support for this. The public believes that through the use of adequate educational methods, good results may be achieved with students with special needs. In 1990 and 1995, surveys of public opinion about education were conducted by the National Institute of Public Education, based on a representative sample of 1,000 people (Köpatakiné Mészáros \& Singer, 2005). In a seven-item ranking in order of importance, support for students with special needs placed last in 1990, but third in 1995. This shows a change in the public's opinion towards the importance of special needs education (Köpatakiné Mészáros \& Singer, 2005).

The conclusion of the present overview is that, up to the present, people with special needs in Hungary, and many other Member States of the EU as well, continue to face significant barriers to real access to education and employment, and that discrimination still remains a major issue within a larger European context. It is important that civil society has a dialogue with government concerning the human rights of people with special needs. It is very important that special education professionals continuously raise awareness and initiate open discussion of the following issues at local, national, and international levels:

- protecting against multiple discrimination,

- contributing to equal opportunity for people with special needs in every country,

- encouraging the exchange of experiences with good practice and effective strategies,

- reinforcing cooperation between government, social agencies (such as social services and NGOs), the private sector, voluntary sector groups, and people with special needs and their families,

- improving communication about disability, and promoting a positive image of people with special needs (Toth, 1997b),

- raising awareness of the various kinds of disability and the heterogeneity of people with special needs (Köpatakiné Mészáros \& Singer, 2005),

- paying special attention to equality in education, in order to encourage and support full inclusion into society (Toth, 2001), and

- promoting the development of international cooperation among professionals involved in the education of people with special needs (Halász, 2004).

The movement towards inclusive education, advocacy training, and transition to regular employment is worldwide (UNESCO, 2004). Economic factors shall not be the cause of any country's lacking results in the above mentioned goals. Exceptional results have occurred in some of the poorest countries (e.g., South Africa, Laos, and Lesotho), where there is political will and a commitment to give priority to people with disabilities (Department of Education, 2001; Holdsworth, Sacklokham, Phommaboud, \& Inthirath, 1997; Mariga \& Phachaka, 1993). 


\section{G. Toth}

Of course, different countries have different education systems and different attitudes towards inclusive education. Cultural factors and traditional educational services are the main source of such differences. On the other hand, there is a strong international trend toward educational reforms in both developed and developing countries. However, I think that the biggest problem in developing progress in inclusive education and transition to employment is not the economic situation or lack of legislation, but rather negative attitudes on the part of political parties, local boards of education, teachers, social-welfare professionals, parents, and other family members..

Looking over the latest literature in the field of inclusive education and employment of people with special needs, I found a lot of good practice on the ground (e.g., Meijer, 2001; Salva Vita Foundation, 2000, 2004). These existing models of good practice should be followed and culturally adapted on a more extensive scale all over the world. The international literature already shows a great deal of information and practice exchange occurring.

The future international standard is unquestionably the idea of full-inclusion. We all should be working towards this goal.

\section{References}

Act LXI of 2003 on the Amendment of Act LXXIX of 1993 on Public Education (2003) Gazette, 2003/85, 16 July 2003.

Croll, P. \& Moses, D. (2000) Ideologies and utopias: Education professionals' view of inclusion. European Journal of Special Needs Education, 15, 1-12.

Gurriculum Guidelines for Children with Disabilities (1997) Ministry of Education and Public Schooling Decree Directive 23/1997 (VI.4.) on Curriculum Guidelines for School Education of Children with Disabilities. Ministry of Education, Budapest.

Department of Education (2001) Special Needs Education: Building an inclusive education and training system (Education White Paper 6). ELSEN Directorate, Pretoria.

Dew-Hughes, D. \& Blandford, S. (1999) The social development of children with severe learning difficulties: A case study of an inclusive education initiative between two primary schools in Oxfordshire, UK. Down's Syndrome Research and Practice, 6, 1-11.

Disabled Persons Act (2004) Act XXVI of 1998 on the Rights and Ensuring the Equal Opportunities of People with Disabilities, Gazette 1998/28, 1 April 1998; Last amended by Act XXVI of 2004 on the Amendments of Certain Social and Health Care Acts. Gazette, 2004/56, 26 April 2004.

EADSNE (2003a) Special education across Europe in 2003: Trends in provision in 18 European countries. European Agency for Development in Special Needs Education, Middelfart, Denmark.

EADSNE (2003b) Special needs education in Europe: Thematic publication. European Agency for Development in Special Needs Education, Middelfart, Denmark.

EIU (2006) Economist intelligence unit maintains negative outlook on Hungary's sovereign rating despite fiscal package. Economist Intelligence Unit. Retrieved July 26, 2006,

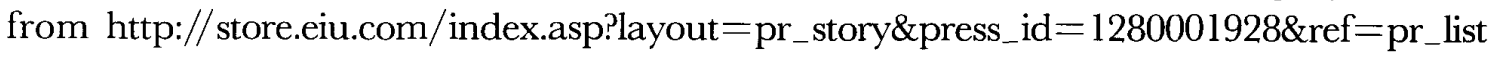




\section{Inclusive Education and Social Inclusion in Hungary}

Employment and Social Care of People with Altered Working Capacity (2004) Joint Decree of the Ministry of Employment and Labour, the Ministry of Health, Social and Family Affairs, and the Ministry of Finance 12/2004 (VI.16) on the Amendment of Joint Decree of the Ministry of Health and the Ministry of Finance 8/1983. (VI.29) on Employment and Social Care of People with Altered Working Capacity. Gazette, 2004/ 48(16).

EUMAP (2005) Rights of people with intellectual disabilities: Access to education and employment. Monitoring Report. Open Society Institute (European Union Monitoring and Advocacy Program and Mental Health Initiative), Gyoma, Hungary.

European Council (1990) Resolution of the Council and the Ministers for Education meeting with the Council of 31 May 1990 concerning integration of children and young people with disabilities into ordinary systems of education. Official Journal of the European Communities, G 162, 03. 07. 1990.

European Council (1992) Treaty on European Union (Maastricht, 7 February 1992). Official Journal of the European Communities, C 191, 29. 07. 1992.

European Council (1997) Treaty of Amsterdam amending the treaty on European Union, the treaties establishing the European Communities and related acts: Chapter 3; Education, vocational training and youth, Article 149 (ex Article 126). Official Journal of the European Communities, G 340, 10. 11. 1997.

European Council (2001) Council Decision of 3 December 2001 on the European Year of People with Disabilities 2003. Official Journal of the European Communities, L 335, 19. 02. 2001, 15-20.

European Council (2003a) Council Resolution of 5 May 2003 on equal opportunities for pupils and students with disabilities in education and training. Official Journal of the European Communities, C 134, 07. 06. 2003.

European Council (2003b) Council Resolution of 6 February 2003 on "eAccessibility": Improving the access of people with disabilities to the knowledge-based society. Official Journal of the European Communities, G 39, 18. 02. 2003.

European Council (2003c) Council Resolution of 6 May 2003, on accessibility of cultural infrastructure and cultural activities for people with disabilities. Official Journal of the European Communities, G 134, 07. 06. 2003.

Evans, J. \& Lunt, I. (2002) Inclusive education: Are there limits? European Journal of Special Needs Education, 17, 1-14.

Fujita, H. (2000) Education reform and education politics in Japan. American Sociologist, 30, $42-57$.

Gordosné, A. (Ed.) (2004) Remedial pedagogy: Education and therapy. Medicina Press, Budapest. (in Hungarian)

Halász, G. (2004) Education of children with SEN: European politics and local challenges. New Pedagogical Reviewe, 2004/02, 28-37. (in Hungarian)

Hand in Hand Foundation (2003) People with multiple severe intellectual disabilities living with their families in Hungary: A report. Kéz a Kézben Alapítvány (HHF), Budapest. (in Hungarian)

HCSO (2001) Population Census 2001 (Hungarian Central Statistical Office). Retrieved 25 July, 2006, from http://www.nepszamlalas.hu/eng/index.html

HCSO (2005) Mikrocenzus 2005 in English (Hungarian Central Statistical Office). 


\section{G. Toth}

Retrieved 25 July, 2006, from http://www.nepszamlalas.hu/mc2005/mc2005_eng/

Holdsworth, J. C., Sacklokham, K., Phommaboud, C., \& Inthirath, S. (Eds.) (1997) Management of the integrated education programme: Guideline. (English ed.) Integrated Education National Project Board, Ministry of Education, Vientiane, Lao PDR.

Hornby, G. (1999) Inclusion or delusion: Can one size fit all? Support for Learning, 14, 152157.

Kim, B. H. (2006) Present situation and problems of inclusive education in Korea: An international comparison. Japanese Journal of Special Education, 43, 449-457.

Köpatakiné Mészáros, M. \& Singer, P. (2005) Country report on the assessment policy of students with special education needs in Hungary. In Centre for School Development and Integration (Ed.), Country report. National Institute for Public Education for the Hungarian Ministry of Education, Budapest.

Mariga, L. \& Phachaka, L. (1993) Integrating children with special needs into regular primary schools in Lesotho - Report of a feasibility study. Ministry of Education, Maseru, Lesotho.

Meijer, C. J. W. (Ed.) (2001) Inclusive education and effective classroom practices. European Agency for Development in Special Needs Education, Middelfart. Denmark.

Mittler, P. (2000) Working towards inclusive education: Social contexts. David Fulton Publishers, London.

Mittler, P. (2005) Building bridges between special and mainstream services. Asia Pacific Disability Rehabilitation Journal, 16(1), 3-15.

National Disability Programme (1999) Parliamentary Order 100/1999 (XII. 10.) on the National Programme on Disability Affairs. Budapest, Hungary.

NISE (2000) Country report of Japan: 20th APEID Regional Seminar on Special Education. National Institute of Special Education (Japan), Yokosuka.

Putnam, J. W. (Ed.) (1998) Cooperative learning and strategies for inclusion: Celebrating diversity in the classroom (2nd ed.). Paul, H. Brookes, Baltimore, Maryland.

Salva Vita Foundation (2000) Supported employment: People with intellectual disability on the open labour market. Salva Vita Foundation, Budapest. (in Hungarian)

Salva Vita Foundation (2004) The practice makes it: Inclusive employment programme for people with intellectual disabilities. FGYK (Opportunities for People with Disabilities Public Foundation), Budapest. (in Hungarian)

Toth, G. (1997a) Physical education curriculum of special classes for children with speech and language disorders: Physical education and sport curriculum. (No. OKI97GYPMASTES1-6.) National Institute of Public Education (OKI), Budapest.

Toth, G. (1997b) Supportive communication between the helper and client: The dialogue model. In T. Foldes, E. Z. Markne, \& J. Zavoti (Eds.), Communication and disorder. Association for Children with Developmental Disability, Sopron, Hungary, 46-51.

Toth, G. (2001) Promises of autonomy: Symbols and dimensions of adulthood with developmental disorder. In E. Z. Markne, J. Zavoti, \& T. Foldes (Eds.), Educational autonomy or autonomy in the education. Association for People with Developmental Disability, Sopron, Hungary, 188-204.

UNESGO (1990) The World Declaration on Education for All: Section 1, Article 1 (Jomtien, Thailand, 5-9 March 1990). Retrieved 25 July 2006, from http://www. unesco.org/education/efa/ed_for_all/

UNESCO (1994) The Salamanca Statement and Framework for Action on Special Needs 
Inclusive Education and Social Inclusion in Hungary

Education, adopted by the World Conference on Special Needs Education: Access and Quality (Salamanca, Spain, 7-10 June, 1994). United Nations Educational, Scientific and Cultural Organisation, Paris.

UNESCO (2001) Open file on inclusive education: Support materials for managers and administrators. Section for Combating Exclusion through Education, UNESCO, Paris.

UNESCO (2004) Changing teaching practices: Using curriculum differentiation to respond to students' diversity. Inclusive Education Unit, UNESCO, Paris.

Whittle, R. (1998) Disability discrimination and the Amsterdam Treaty. European Law Review, 23(1), 50-58.

Whittle, R. \& Cooper, J. (1999) Enforcing the rights and freedoms of disabled people: the role of transnational law (Part II). Mountbatten Journal of Legal Studies, 3(1), 3-32.

World Health Organization (1992) International Classification of Diseases (ICD-10). (10th rev. ed.) Author, Geneva.

-Received August 3, 2006; Accepted February 17, 2007-- 